\title{
Antiseptics and antimicrobials for the treatment and management of chronic wounds: a systematic review of clinical trials
}

\author{
Justyna Cwajda-Białasik ${ }^{1,2}$, Paulina Mościcka ${ }^{1,2}$, Maria T. Szewczyk $k^{1,2}$ \\ 'Department of Perioperative Nursing, Ludwik Rydygier Collegium Medicum in Bydgoszcz, Nicolaus Copernicus University in Torun, Poland
} ${ }^{2}$ Outpatient Department for Chronic Wound Management, Antoni Jurasz University Hospital No. 1, Bydgoszcz, Poland

Adv Dermatol Allergol 2022; XXXIX (1): 141-151

DOI: https://doi.org/10.5114/ada.2022.113807

\begin{abstract}
Introduction: The development of the field related to the treatment of wounds has resulted in the appearance of new antimicrobial active ingredients.

Aim: To analyse, evaluate and systematize the available scientific evidence of the effectiveness and safety of antiseptic preparations intended for the treatment of chronic wounds.

Material and methods: We conducted a literature review using the advanced search engine in the PubMed database. We used a combination of two English keywords, i.e.: "antiseptic" and "chronic wound". We have selected only clinical, randomized controlled trials.

Results: We obtained a total of 825 items (674 full-text works). We included 29 studies in the review. The most frequently evaluated preparation was octenidine dihydrochloride and povidone iodine (pharmacological drugs). Preparations containing polyhexanide, products based on hypochlorite, reactive oxygen species, $1 \%$ acetic acid, and specialized antibacterial dressings were also assessed. The new generation of antimicrobial preparations were highly effective, both in the prevention and treatment of infections, and were well tolerated by the tissues and do not interfere with the healing process. The best tolerated and most effective antiseptic was OCT/PE. For cleaning, we recommend OCT-based irrigation fluids, $\mathrm{PHMB}$, or hypochlorite. The maintenance of the antimicrobial effect during the therapy was ensured by a compatible dressing.

Conclusions: An antiseptic alone is not effective enough and the therapeutic effect depends to the greatest extent on properly selected causal therapy, preceded by thorough diagnostics.
\end{abstract}

Key words: antiseptic, chronic wound, pharmacological drug, medical device.

\section{Introduction}

The term "antisepsis" (Greek for anti - against and sepsis - rot) literally means "prevention of rotting". It was first used in a practical context by the Scottish surgeon John Pringle in 1750 in order to define treatments and substances that prevent wound rotting [1]. The first antiseptic preparations (e.g. phenol, carbolic acid, chlorine compounds) were simple and extremely irritating, yet for some time they played a significant role and successfully reduced the number of infections [1, 2]. Nowadays, with changes in microbial characteristics of wounds and the development of the discipline, expectations of antiseptics have increased. It is expected that the antiseptic preparation will not only be effective against microorganisms, but also safe and even beneficial, supporting and stimulating the wound healing process. Kramer et al. [2] published a list of antiseptics contraindicated in wound treatment, including due to their increased cytotoxicity, their inhibitory effect on the healing process (e.g. enzyme inactivation, protein coagulation), local irritation and drying of the wound surface. It has been proven that some of the substances used so far show no or quite weak biocidal effect in in vivo conditions, which additionally questions the justification for their use. According to Kramer, the so-called "blacklist" includes, among others, hydrogen peroxide, ethanol, dye-stuff, silver sulfadiazine, chloramine T, or ethacridine lactate. Moreover, topical ap-

Address for correspondence: Justyna Cwajda-Białasik PhD, Department of Perioperative Nursing, Nicolaus Copernicus University, Ludwik Rydygier Collegium Medicum, Bydgoszcz, Poland, phone: +48 5059393 98, e-mail: jcwajda@wp.pl Received: 8.11.2020, accepted: 24.11.2020. 
plication of antibiotics to the wound is contraindicated [2-6].

The development of the field related to the treatment of wounds has resulted in the appearance of new antimicrobial active ingredients on the market. On the one hand, it increased the possibility of choice, on the other hand, it raised many doubts and questions, including which of the preparations is the most optimal, how the antiseptics react on the skin and in wounds (acute, chronic and complicated), what are the prophylactic and therapeutic indications for their use. The situation is further complicated by the fact that preparations containing an antimicrobial agent can be registered in two categories, i.e. as a pharmacological drug - PG (it is then a "classic antiseptic") or as a medical device - MD. Their distinction is crucial when choosing the optimal method of wound treatment and care $[2-4,6]$. It also has a legal justification. According to the definition [2-8] and applicable law [8-11], an "antiseptic" is a pharmacological drug which destroys and / or inhibits the growth of (kills) microorganisms on the skin, mucous membranes and in wounds. Antiseptic (drug) should exhibit a pharmacological, metabolic and/or immunological bactericidal or bacteriostatic effect. On the other hand, the medical device - even if it contains an antimicrobial substance - is basically not intended to kill, but only to physical-

Table 1. Criteria differentiating antiseptics (pharmacological drugs, drugs) and medical devices (other preparations containing substances with antimicrobial activity, not being a drug, but in accordance with their intended use for cleaning, irrigation and wound care)

\begin{tabular}{|c|c|c|}
\hline Category & Pharmacological drug, PD & Medical device, MD \\
\hline $\begin{array}{l}\text { Mechanism } \\
\text { of action }\end{array}$ & $\begin{array}{l}\text { Pharmacological, biochemical, metabolic and/ } \\
\text { or immunological mechanism leading to the } \\
\text { inhibition, prevention or killing of bacteria } \\
\text { (biocidal effect) }\end{array}$ & $\begin{array}{l}\text { The primary mechanism of action is physical cleansing (i.e. } \\
\text { washing/lavaseptic, absorption, moisture regulation or } \\
\text { irreversible physicochemical binding of microorganisms) - the } \\
\text { antimicrobial effect is only due to the addition of preservatives }\end{array}$ \\
\hline Composition & $\begin{array}{l}\text { Full description of the composition including the } \\
\text { individual components of the preparation and } \\
\text { their quantity (concentration, proportions, etc.), } \\
\text { indications and microbiological effectiveness }\end{array}$ & $\begin{array}{l}\text { Composition taking into account the main components of the } \\
\text { preparation (quantitative composition may be given but is not } \\
\text { required) }\end{array}$ \\
\hline $\begin{array}{l}\text { Registration } \\
\text { category* }\end{array}$ & $\begin{array}{l}\text { Pharmacological drug - is an ingredient or mixture } \\
\text { of ingredients with properties for the prevention or } \\
\text { treatment of disease in humans and animals; } \\
\text { Antiseptic - is a medicinal product, including } \\
\text { a veterinary medicinal product, which destroys } \\
\text { microorganisms and inhibits their growth, and is } \\
\text { applied topically to damaged tissues, in particular } \\
\text { wounds and burns, and to the patient's skin before } \\
\text { procedures. } \\
\text { Antiseptics always contain an antimicrobial active } \\
\text { ingredient. }\end{array}$ & $\begin{array}{l}\text { Medical device - is a tool, instrument, apparatus, equipment, } \\
\text { material or other article used alone or in combination, including } \\
\text { software necessary for the proper application of the product, } \\
\text { intended by the manufacturer for use in humans for the diagnosis, } \\
\text { prevention, monitoring or alleviation of the course of disease. } \\
\text { Category II products - characterized by only a physicochemical } \\
\text { mechanism of action and the lack of parameterized biological } \\
\text { activity. } \\
\text { Category III products - combine the physicochemical mechanism of } \\
\text { action of surfactants with the biocidal activity of an antimicrobial } \\
\text { substance }\end{array}$ \\
\hline $\begin{array}{l}\text { Efficiency } \\
\text { and safety }\end{array}$ & $\begin{array}{l}\text { Confirmed both in in vitro studies, but above all in } \\
\text { clinical trials }\end{array}$ & Not always confirmed by in vivo tests \\
\hline Indications & Prevention and treatment of wound infections & $\begin{array}{l}\text { Wound cleansing, supporting the prevention and treatment of } \\
\text { wound infections }\end{array}$ \\
\hline $\begin{array}{l}\text { An example } \\
\text { of active } \\
\text { ingredients }\end{array}$ & $\begin{array}{l}10 \% \text { PVP-I, polyvinylpyrrolidone-iodine } \\
0.1 \% \text { OCT/PE - octenidine dihydrochloride/ } \\
\text { phenoxyethanol } \\
\text { CHX - chlorhexidine }\end{array}$ & $\begin{array}{l}\text { In irrigation fluids (lavaseptics): } \\
\mathrm{OCT} \text { - octenidine dihydrochloride } \\
\mathrm{PHMB} \text { - polyhexanide (in combination with } \\
\text { undecylenamidopropyl betaine - Betaine) } \\
\mathrm{NaOCl} / \mathrm{HOCl} \text { - hypochlorite (e.g. sodium hypochlorite/ } \\
\text { hypochlorous acid) } \\
\text { In dressings/gel: } \\
\mathrm{Ag} \text { - metallic and ionic silver, salts, complexes and compounds } \\
\mathrm{OCT} \text { - octenidine dihydrochloride } \\
\mathrm{PHMB} \text { - polyhexanide (+ Betaine) } \\
\mathrm{PVP-iodine} \\
\mathrm{CHX} \text { - chlorhexidine } \\
\text { Active carbon }\end{array}$ \\
\hline
\end{tabular}

*based on: Definition of the Office for Registration of Medicinal Products, Medical Devices and Biocidal Products, Pharmaceutical Law Act of 6 September 2001 (Journal of Laws of 2020, item 944), Act on medical devices of 20 May 2010 (Journal of Laws of 2020, item 186), Regulation of the Minister of Health on the determination of groups of medicinal products and the requirements for the results of tests of these products of 11 August 2005 (Journal of Laws of 24 August 2005), Kramer A, et al. Consensus on wound antisepsis: update 2018. Skin Pharmacol Physiol 2018; 31: 28-58. Bartoszewicz M, et al. Principles of local and general management in chronic wounds/ulcers covered by the infection process. Infection Forum 2019; 10: 1-30. 
ly remove contaminants and microorganisms. Medical devices are usually intended for cleaning and irrigation of wounds, as well as supporting the prevention and treatment of infection, while antiseptic preparations are used only in clinically justified situations $[3,4,6]-$ in the prevention of infections, in contaminated acute wounds (e.g. traumatic wounds, after bites, gunshot wounds), in the prevention of surgical site infection and in order to decolonize wounds inhabited by multidrug-resistant microorganisms. Therapeutically, the antiseptic is indicated in the treatment of clinically overt (i.e. symptomatic) local and generalized infection [2, 6, 12-14]. However, routine antisepsis of clean and colonized wounds is not recommended, except for individual indications in patients at risk. Table 1 summarizes the most important information on the differences between medicinal products and medical devices applied to wounds.

In practice, the greatest difficulty is choosing the optimal preparation for the treatment of chronic wounds and ulcers. Regardless of their aetiology, chronic wounds require long-term therapy, and the applied preparation is applied over a large area of exposed and damaged tissues, unlike acute, traumatic and postoperative wounds. It should be mild and non-toxic. Moreover, chronic wounds are burdened with extensive inflammation, and the profuse exudate may contain factors that modify the ability of the antimicrobial substance to eradicate pathogens [3]. The preparation is effective in vitro and may change the action in the protein-rich environment of the wound. Therefore, experts emphasize that the measure of the effectiveness of this preparation is the assessment of its effectiveness and safety, primarily in clinical conditions $[2,6,14]$.

\section{Aim}

The aim of this study was to analyse, evaluate and systematize the available scientific evidence on the effectiveness and safety of antiseptic preparations intended for the treatment of chronic wounds. The analysis included clinical trials and research conducted in vivo, obtained from the publicly available English-language search engine PubMed.

\section{Material and methods}

We conducted a literature review using the advanced search engine in the PubMed database on the website: www.pubmed.ncbi.nlm.nih.gov/. We used a combination of two English key words, i.e.: "antiseptic" or "antisepsis" and "chronic wound". There are no restrictions on the publication date and language. We have selected only full-text works that meet the criteria of "clinical trial" and "randomized controlled trial". For the final qualification of the research, we analysed the titles and abstracts of articles that meet the adopted criteria (Table 2).

The online database review and the qualification of papers based on the title and content of the abstract were carried out independently by two people specializing in the treatment of chronic wounds. The results were compared, standardized, and then the full research texts were analysed.

\section{Results}

In the preliminary search, we obtained a total of 825 items, 674 of which were full-text works. After elimination of works that did not meet the criteria of a "clinical trial" and "randomized controlled trial", 68 articles remained. We excluded some of them on the basis of the title of the article or the content of the abstract, which indicated that the study did not meet the adopted criteria. Two articles were classified differently by the researchers and their exclusion from the analysis was a controversial issue. The study by Gasca-Lozano et al. [15] assessed the effectiveness of topical application of a gel containing pirfenidone (PFD) and modified diallyl disulfide oxide (M-DDO). PFD is a strong modulator of the extracellular matrix, and M-DDO has antimicrobial and antiseptic properties. We excluded this study because the PFD + M-DDO gel was used on uninfected wounds, and the aim of the study was to evaluate the effectiveness of the preparation in comparison with ketanserin. The study by Bishop et al. [16] compared the effectiveness of the biologically active tripeptide copper complex $0.4 \%$ cream (having growth factor properties) with silver sulfadiazine in the treatment of venous leg ulcers. Due to the local use of the antibiotic and the lack of use of the

Table 2. Criteria for qualifying the article for analysis

\begin{tabular}{ll}
\hline Study type & Randomized, single or multicentre, with or without control, or observational with a control group \\
\hline Study group & $\begin{array}{l}\text { Adult patients with chronic wounds, regardless of aetiology (excluding neoplastic and unclassified } \\
\text { wounds, as well as wounds and lesions involving mucous membranes) }\end{array}$ \\
\hline $\begin{array}{l}\text { Interventions } \\
\text { A preparation containing an antimicrobial substance, regardless of the form (liquid, gel, powder, } \\
\text { impregnation), intended for the care and/or treatment of chronic wounds }\end{array}$ \\
\hline $\begin{array}{l}\text { Control group } \\
\text { of the preparation }\end{array}$ & $\begin{array}{l}\text { Standard care or other alternative antimicrobial treatment of wounds at risk of infection or infected } \\
\text { complications, others }\end{array}$ \\
\hline
\end{tabular}


antiseptic preparations, the study was excluded from the final analysis.

Ultimately, we included 29 papers in the review, most of them published in the last 10 years (i.e. 16 (55.2\%) publications), 10 (34.5\%) publications constituted multicentre studies. The studies were most often carried out in a group of patients with venous leg ulcer (VLU), leg ulcer of vascular aetiology, diabetic foot ulcer (DFU), pressure ulcers (PU) and other chronic wounds. The most frequently evaluated preparation was octenidine dihydrochloride (OCT) at a concentration of $0.1 \%$ and in combination with $2 \%$ phenoxyethanol (PE) solution, registered as a pharmacological drug [17-21] or at a concentration of $0.05 \%$ as a wound irrigation solution and wound gel registered as medical devices [17, 21-23]. Preparations containing iodine were used in the form of povidone iodine - PVP-I (drug) [22, 24-28] or cadexomer-iodine (medical devices) [29-32]. Several studies have assessed preparations containing polyhexanide (polyhexamethylene biguanide, $\mathrm{PHMB}$ ) without or in combination with undecylenamidopropyl betaine (medical devices) [20, 33, 34]. The group of assessed antimicrobial preparations also included dressings containing various forms of $\mathrm{Ag}$ [17, 31, 35-40]. Single studies evaluated products based on hypochlorite [20], reactive-oxygen species [20], 1\% acetic acid [41], N-chlorotaurine and chloramine $\mathrm{T}$ [42] and combinations of two or more of the above-mentioned methods [15, 17, 20, 32]. One of the studies reported the results of research on a new specialized dressing containing light-activated nanofiber textiles [43]. In most of the analysed studies, microbiologically neutral irrigation fluids (0.9\% NaCl, Ringer solution), specialized dressings, physical methods (e.g. cold atmospheric plasma), systemic antibiotics or simply standard medical care in accordance with the guidelines were used. Due to the varied methodology of the research, the assessed parameters and the different observation time, we were not able to perform a statistical evaluation in the form of a meta-analysis, but only a descriptive analysis. Detailed results are presented in Table 3.

\section{Discussion}

The keyword "antiseptic" entered into the search engine included products which included both pharmacological drugs and medical devices. Following the recommendations of experts [2-6, 14, 44, 45] we tried to distinguish between these two types of products. In some studies, the registration category of the preparation was not given, but only its type, concentration and form of the used antimicrobial substance. This allowed us to categorize according to the registration status of products in force in Poland. In the category of drugs for use on wounds, the following are registered: 0.1\% OCT/PE and 10\% PVP-I [3]. Other products containing antimicrobial substances have the status of medical devices [3-5, 45].
All the currently recommended preparations, which have obtained positive recommendations in in vitro studies, have also shown high effectiveness in the environment of chronic wounds, such as VLUs, DFUs, PUs and others [17-21, 24, 25, 27, 28]. The tolerance of antiseptics varied. It is described, among others, by Biocompatibility Index (BI) determined in vitro. The optimal $\mathrm{BI}$ is $>1$. It is characterized by antiseptics of high antimicrobial effectiveness and low cytotoxicity [46]. Such a value of the biocompatibility index was demonstrated for OCT $(\mathrm{BI}=1.7 ; 2.1)$ and $\mathrm{PHMB}(\mathrm{BI}=1.5 ; 1.4)$. However, in clinical conditions, the tolerance of the antiseptic is compared with isotonic Ringer's solution, $0.9 \% \mathrm{NaCl}$ or a neutral hydrogel [2, 6, 45-47].

The good tolerance of antiseptics with OCT was confirmed in a 12-week multicentre randomized study, which compared the efficacy and safety of the OCT and Ringer solution. The rates of the healing process did not differ significantly between the groups, but the rates of adverse events and complications, including pruritus, local irritation and pain were significantly lower in OCT [20]. The results of the study by Calow et al. [21] also confirmed the good tolerability of OCT in chronic wounds. During the 2-week observation period, allergic reactions and signs of contact dermatitis were assessed after the application of the medicinal product with OCT/PE. Allergic complications were sporadic (4.4\% of patients). The relationship with the applied antiseptic was confirmed in 3\% of the respondents. The results of patch tests showed that a positive skin reaction was associated with the action of phenoxyethanol and the excipient - cocamidopropyl betaine, but not octenidine [21]. In a study comparing the antimicrobial efficacy of OCT versus cold atmospheric pressure argon plasma (a method of physical wound cleansing), the tissue tolerance of both methods was similar, but OCT showed a significantly higher microbial reduction (immediately after cleaning the wound as well as after the end of the entire 2-week treatment cycle) [18].

lodine povidone, an iodophor antiseptic, despite its high effectiveness, did not show such favourable tolerance in the environment of chronic wounds. Various forms and concentrations of iodine preparations have been evaluated in clinical trials, including PVP-I (solution, ointment), cadexomer iodine (powder, ointment, dressing) and povidone iodine liposome hydrogel (PVP-I-L). The results of the studies varied depending on the type of control therapy. Better results were achieved with the combination of standard care and antiseptic action of iodophors than without their use [24, 25, 27, 30], but worse compared to silver dressing [31] and systemic antibiotic therapy [26]. A comparison of the microbial load before and after the use of povidone or iodine dextranomers indicated a statistically significant reduction in the number of bacteria in the wound swab [22] and a lower total bacterial load in the ulcer biopsy material [29]. The beneficial antimicrobial effect was achieved regardless of the 
Table 3. Summary of data from the analysis of clinical trials assessing the efficacy and tolerability of antimicrobial preparations in the treatment of chronic wounds

\begin{tabular}{|c|c|c|c|c|}
\hline Author, year & $\begin{array}{l}\text { Sample size, } n \\
\text { Patient [wound] }\end{array}$ & $\begin{array}{l}\text { Type of } \\
\text { wound }\end{array}$ & Comparison & Results and conclusions \\
\hline $\begin{array}{l}\text { Malone (2019) } \\
\text { [29] }\end{array}$ & $9 / 9$ & DFU & $\begin{array}{l}\text { Cadexomer iodine } 0.9 \% \\
\text { ointment ( } 2 \text { vs. } 6 \text { weeks) }\end{array}$ & $\begin{array}{l}\text { No differences in the results due to the duration of } \\
\text { therapy. Total microbial load and community composition } \\
\text { decrease (assessed by real-time qPCR method and SEM) } \\
\text { - after } 2 \text { weeks and } 6 \text { weeks was comparable }\end{array}$ \\
\hline $\begin{array}{l}\text { Raju (2019) } \\
\text { [30] }\end{array}$ & $41 / 43 / 40$ & VLU & $\begin{array}{l}0.9 \% \text { cadexomer iodine } \\
\text { ointment or powder vs. } \\
\text { standard care ( } 12 \text { weeks) }\end{array}$ & $\begin{array}{l}\text { Significantly better results achieved when standard care } \\
\text { was combined with an antiseptic than with no care }\end{array}$ \\
\hline $\begin{array}{l}\text { Assadian } \\
(2018)[22]\end{array}$ & $\begin{array}{l}11[13] / 20[23] / \\
22[27] / 14[14] / \\
22[23] / 16[16] / \\
31[33] / 17[31] / \\
33[36] / 37[41] / \\
25[28] / 12[14]^{\star}\end{array}$ & $\begin{array}{l}\text { Chronic } \\
\text { wounds } \\
\text { of various } \\
\text { aetiology } \\
\text { (VLU, AU, DFU, } \\
\text { PI, others) }\end{array}$ & $\begin{array}{l}\text { The antibacterial effect of } \\
\text { different irrigation solutions } \\
\text { during a 20-minute wet-to- } \\
\text { moist treatment of chronic } \\
\text { wounds has been studied }\end{array}$ & $\begin{array}{l}\text { All irrigation solutions excluding } 0.9 \% \mathrm{NaCl} \text { and } \mathrm{H}_{2} \mathrm{O}+ \\
\text { lithium-magnesium-sodium-silicate, Sal Maris, nascending } \\
\mathrm{O}_{2} \text { (Biosept), significantly reduce the planktonic bacterial } \\
\text { burden on wounds. The highest reduction was noted at: } \\
\text { cocamidopropyl betaine, zinc, iron, polyhexamethylene } \\
\text { biguanide (Nawalution), then sea salt } 3 \% \text { and } 0.2 \% \text { sodium } \\
\text { hypochlorite (Actimaris Forte } 3 \% \text { ) and } 10 \% \text { povidone-iodine } \\
\text { (PVP-I) solution with } 10 \% \text { free iodine (the most statistically } \\
\text { significant decrease in the number of bacteria), hypochlorite } \\
\text { (ClO-) and hypochlorous acid ( } \mathrm{HClO} \text { ) } \\
57 \text { mg/l (Anosteralyt } 30 \%) \text {. The combination of two } \\
\text { different irrigation solutions did not increase or even reduce } \\
\text { the antibacterial effectiveness }\end{array}$ \\
\hline $\operatorname{Kim}(2018)$ & $22 / 21$ & $\begin{array}{l}\text { Chronic } \\
\text { wounds } \\
\text { of various } \\
\text { aetiology }\end{array}$ & $\begin{array}{l}\text { Biofilm-disrupting wound } \\
\text { gel vs. a triple-antibiotic } \\
\text { ointment (12 weeks) }\end{array}$ & $\begin{array}{l}\text { Greater progress in the healing process in the group } \\
\text { treated with the gel (wound healing: } 71 \% \text { vs. } 24 \% \text { ). } \\
\text { Microbiological analysis showed no correlation between } \\
\text { the presence of bacteria in the wound, or the number of } \\
\text { identified species of microorganisms and the effect on } \\
\text { the healing process }\end{array}$ \\
\hline $\begin{array}{l}\text { Madhusudhan } \\
\text { (2016) [41] }\end{array}$ & $16 / 16$ & $\begin{array}{l}\text { Chronic } \\
\text { wounds } \\
\text { infected with } \\
\text { P. aeruginosa }\end{array}$ & $\begin{array}{l}1 \% \text { acetic acid vs. } 0.9 \% \mathrm{NaCl} \\
\text { (24 weeks) }\end{array}$ & $\begin{array}{l}\text { The duration of treatment required to eliminate the } \\
\text { Pseudomonas from the wounds in the acetic acid group } \\
\text { was on an average } 7 \text { days less than that required by the } \\
\text { saline group }\end{array}$ \\
\hline $\begin{array}{l}\text { Wolcott (2015) } \\
{[44]}\end{array}$ & $15 / 15 / 15$ & $\begin{array}{l}\text { Chronic } \\
\text { wounds } \\
\text { of various } \\
\text { aetiology } \\
\text { (VLU, AU, DFU, } \\
\text { PI others) }\end{array}$ & $\begin{array}{l}\text { Standard care/biofilm- } \\
\text { disrupting wound gel/gel + } \\
\text { standard care (12 weeks) }\end{array}$ & $\begin{array}{l}\text { Significantly higher percentage of the healed area in the } \\
\text { group using the gel or gel in combination with standard } \\
\text { care compared to the standard care alone without the } \\
\text { gel ( } 53 \% \text { vs. } 80 \% \text { vs. } 93 \% \text { ). In this study, the biofilm } \\
\text { structure in wounds and the actual effect of the gel on } \\
\text { the biofilm were not identified }\end{array}$ \\
\hline $\begin{array}{l}\text { Hämmerle \& } \\
\text { Strohal (2014) } \\
\text { [23] }\end{array}$ & $\begin{array}{c}15[15] / 14[17] / \\
15[17]^{*}\end{array}$ & VLU & $\begin{array}{l}\text { OCT gel + specialist } \\
\text { dressing/OCT gel + gauze/ } \\
\text { specialist dressing } \\
\text { ( } 6 \text { weeks) }\end{array}$ & $\begin{array}{l}\text { Significantly better effectiveness (\% healed area) and } \\
\text { tolerance of OCT gel and OCT gel in combination with } \\
\text { a dressing than the dressings alone. No differences } \\
\text { between the groups in the incidence of infections at the } \\
\text { end of therapy }\end{array}$ \\
\hline $\begin{array}{l}\text { Krasowski } \\
\text { et al., } 2015 \\
{[17]}\end{array}$ & $40 / 40$ & VLU & $\begin{array}{l}\text { "Sandwich" (multilayered) } \\
\text { dressing consisted of } \\
\text { layers having different } \\
\text { forms of OCT (gel, solution } \\
\text { and antiseptic) vs. silver } \\
\text { dressing, absorbent } \\
\text { dressing and Ringer's } \\
\text { solution (8 weeks) }\end{array}$ & $\begin{array}{l}\text { Significantly better healing dynamics ( } 1.58 \text { vs. } 0.23 \mathrm{~cm}^{2} / \\
\text { week), higher percentage of the wound area healed: } \\
\text { ( } 58 \% \text { vs. } 14 \%) \text {, degree of microbiological eradication } \\
(21.7 \% \text { vs. } 3.1 \%) \text { after } 4 \text { weeks and after } 8 \text { weeks ( } 69.6 \% \\
\text { vs. } 43.8 \%) \text { and } 1.37 \text { times greater decrease in pain } \\
\text { intensity in the study group }\end{array}$ \\
\hline $\begin{array}{l}\text { Ulrich (2015) } \\
{[18]}\end{array}$ & $10[10] / 10[10]^{\star}$ & $\begin{array}{l}\text { Ulceration } \\
\text { of vascular } \\
\text { aetiology }\end{array}$ & $\begin{array}{l}\text { OCT antiseptic vs. APP } \\
\text { (2 weeks) }\end{array}$ & $\begin{array}{l}\text { Better effectiveness of OCT than APP - higher } \\
\text { microbiological reduction immediately after treatment } \\
\text { ( } 64 \text { vs. } 47 \%) \text { and influence on bacterial density after } \\
2 \text { weeks of therapy ( }-35 \% \text { vs. }+12 \%) \text {. Tolerance of both } \\
\text { methods - comparable }\end{array}$ \\
\hline
\end{tabular}


Table 3. Cont.

\begin{tabular}{|c|c|c|c|c|}
\hline Author, year & $\begin{array}{l}\text { Sample size, } n \\
\text { Patient [wound] }\end{array}$ & $\begin{array}{l}\text { Type of } \\
\text { wound }\end{array}$ & Comparison & Results and conclusions \\
\hline $\begin{array}{l}\text { Klebes (2015) } \\
{[19]}\end{array}$ & 34 (3 groups) & $\begin{array}{l}\text { E.g. ulcers } \\
\text { of various } \\
\text { aetiologies }\end{array}$ & TTP or OCT or TTP + OCT & $\begin{array}{l}\text { Bacterial colonization (assessed before and after } \\
\text { debridement) was most significantly reduced in the TTP } \\
+ \text { OCT combination group compared to monotherapy }\end{array}$ \\
\hline $\begin{array}{l}\text { Woo (2019) } \\
{[35]}\end{array}$ & 34 (2 groups) & $\begin{array}{l}\text { Critically } \\
\text { colonized } \\
\text { wounds }\end{array}$ & $\begin{array}{l}\text { Antimicrobial dressing } \\
\text { with silver alginate powder } \\
\text { vs. normal saline solution } \\
\text { gauze dressing group } \\
\text { ( } 4 \text { weeks) }\end{array}$ & $\begin{array}{l}\text { A significantly better effect (reduction in bacterial load } \\
\text { and reduction in the wound surface) was achieved in the } \\
\text { group using the silver preparation }\end{array}$ \\
\hline $\begin{array}{l}\text { Vanscheidt } \\
(2012)[20]\end{array}$ & $60 / 66$ & VLU & $\begin{array}{l}\text { OCT antiseptic vs. Ringer } \\
\text { solution (12 weeks) }\end{array}$ & $\begin{array}{l}\text { No statistically significant advantage of the OCT } \\
\text { preparation in the parameters of the healing process } \\
\text { (time to wound closure, number of healings, healing } \\
\text { dynamics were comparable). There were fewer } \\
\text { complications in the group using OCT as compared to } \\
\text { the Ringer's solution ( } 16.7 \text { vs. } 28.8 \% \text { ) }\end{array}$ \\
\hline $\begin{array}{l}\text { Sibbald (2012) } \\
\text { [33] }\end{array}$ & $23 / 22$ & $\begin{array}{l}\text { Lower limb } \\
\text { ulceration }\end{array}$ & $\begin{array}{l}\text { PHMB foam dressing vs. } \\
\text { foam dressing (4 weeks) }\end{array}$ & $\begin{array}{l}\text { The use of PHMB foam dressing was a significant } \\
\text { predictor of reduced wound superficial bacterial burden. } \\
\text { PHMB foam dressing successfully reduced chronic wound } \\
\text { pain and bacterial burden }\end{array}$ \\
\hline $\begin{array}{l}\text { Arenbergerova } \\
\text { (2012) [43] }\end{array}$ & $84 / 39 / 39$ & VLU & $\begin{array}{l}\text { Polyurethane fabric made } \\
\text { of nanofibers (NT, nanofibre } \\
\text { textile) with an admixture } \\
\text { of tetraphenylporphyrin } \\
\text { - TPP (photosensitizer) } \\
\text { subjected to photo } \\
\text { exposure vs. NT without } \\
\text { TPP and NT with TPP kept } \\
\text { in the dark }\end{array}$ & $\begin{array}{l}\text { High antibacterial effectiveness of light-activated, } \\
\text { antibacterial nanofibers with TPP admixture (significant } \\
\text { inhibition of bacterial growth, reduction in the wound } \\
\text { area by } 35 \% \text { and pain reduction by } 71 \% \text { ). Bacterial } \\
\text { photoinactivation, dependent on the production of highly } \\
\text { reactive, short-lived singlet oxygen } \mathrm{O}_{2}(1 \mathrm{Dg}) \text {, resulted in } \\
\text { a relatively superficial antibacterial effect and did not } \\
\text { interfere with the ulcer healing process }\end{array}$ \\
\hline $\begin{array}{l}\text { Romanelli } \\
\text { (2010) [34] }\end{array}$ & $20 / 20$ & VLU & $\begin{array}{l}\text { PHMB solution vs. } 0.9 \% \\
\mathrm{NaCl} \text { (4 weeks) }\end{array}$ & $\begin{array}{l}\text { In the group treated with } \mathrm{PHMB} \text {, a favourable decrease in } \\
\text { wound } \mathrm{pH} \text { (from } 8.9 \text { to } 7.0 \text { ) was achieved, in the control } \\
\text { group the } \mathrm{pH} \text { was stable at } 8.5 \text {. In the study group, better } \\
\text { tolerance, pain reduction and odour absorption }\end{array}$ \\
\hline $\begin{array}{l}\text { Woo (2010) } \\
{[35]}\end{array}$ & $20 / 22$ & $\begin{array}{c}\text { Infected } \\
\text { chronic } \\
\text { wounds } \\
\text { of various } \\
\text { aetiology } \\
\text { (VLU, AU, DFU, } \\
\text { PI, others) }\end{array}$ & $\begin{array}{l}\text { Silver alginate wound } \\
\text { dressing vs. alginate } \\
\text { dressing ( } 2 \text { weeks) }\end{array}$ & $\begin{array}{l}\text { The regression of local signs of infection, local tolerance, } \\
\text { acceptability and usefulness were similar for the two } \\
\text { dressings. However, silver alginate wound dressing } \\
\text { improved the bacteriological status of the wounds }\end{array}$ \\
\hline $\begin{array}{l}\text { Miller (2009) } \\
\text { [31] }\end{array}$ & $133 / 133$ & VLU, MU & $\begin{array}{l}\text { Cadexomer iodine vs. } \\
\text { nanocrystalline silver } \\
\quad(12 \text { weeks })\end{array}$ & $\begin{array}{l}\text { The performance of each of the two antimicrobials was } \\
\text { comparable in terms of the overall healing rate and } \\
\text { the number of wounds healed. However, use of silver } \\
\text { compounds was associated with a quicker healing rate } \\
\text { during the first } 2 \text { weeks of treatment and in wounds that } \\
\text { were larger, older, and had more exudate }\end{array}$ \\
\hline $\begin{array}{l}\text { Kotz (2009) } \\
{[37]}\end{array}$ & 126 & $\begin{array}{l}\text { Chronic } \\
\text { wounds with } \\
\text { high exudate } \\
\text { and risk of } \\
\text { infection }\end{array}$ & $\begin{array}{l}3 \text { types of } \mathrm{Ag} \text { foam dressing } \\
\text { (adhesive, non-adhesive } \\
\text { and sacral) }(\mathrm{Me}=21)\end{array}$ & $\begin{array}{l}\text { Non-comparative assessment of silver foam dressings } \\
\text { - all were well tolerated ( } 88.3 \% \text { of wounds). Clinical } \\
\text { symptoms of infection were reduced (from } 68.1 \% \text { to } 31 \% \text { ) } \\
\text { or cured (clinical infection in the final evaluation only in } \\
8.5 \% \text { of patients) }\end{array}$ \\
\hline $\begin{array}{l}\text { Calow (2008) } \\
{[21]}\end{array}$ & 251 & $\begin{array}{l}\text { Chronic } \\
\text { wounds } \\
\text { of various } \\
\text { aetiology } \\
\text { (VLU, AU, DFU, } \\
\text { PI, others) }\end{array}$ & $\begin{array}{l}\mathrm{OCT} / \mathrm{PE} \text { ( } 2 \text { weeks) without } \\
\text { any control group }\end{array}$ & $\begin{array}{l}\text { The presence of contact dermatitis after OCT/PE was } \\
\text { assessed. Local symptoms of contact dermatitis in } n=11 \\
\text { out of } 251(4.4 \%) \text {. Patch test undiluted: } 7 / 7 \text { and diluted: } \\
4 / 7 \text {. ROAT: } 5 \text { by } 7 \text {; Improvement after withdrawal of } \\
\text { the allergen: } 8 / 8 \text {. Ambiguous allergic reaction - rather } \\
\text { related to the excipient }\end{array}$ \\
\hline
\end{tabular}


Table 3. Cont.

\begin{tabular}{|c|c|c|c|c|}
\hline Author, year & $\begin{array}{l}\text { Sample size, } n \\
\text { Patient [wound] }\end{array}$ & $\begin{array}{l}\text { Type of } \\
\text { wound }\end{array}$ & Comparison & Results and conclusions \\
\hline $\begin{array}{l}\text { Hauser (2006) } \\
\text { [24]; Vogt } \\
\text { (2006) [25] }\end{array}$ & $83 / 84$ & $\begin{array}{l}\text { Skin graft } \\
\text { collection sites } \\
\text { and locations } \\
\text { (chronic } \\
\text { wounds, } \\
\text { burns) }\end{array}$ & $\begin{array}{l}\text { Povidone iodine liposome } \\
\text { hydrogel (PVP-I-L) 3\%+ } \\
\text { soft paraffin dressing vs. } \\
\text { soft paraffin dressing alone } \\
\text { (until the wound is healed) }\end{array}$ & $\begin{array}{l}\text { A significantly better microbicidal activity and tissue } \\
\text { tolerability of the PVP-I-L hydrogel compared to } \\
\text { conventional PVP-I formulations was shown. PVP-I-L } \\
\text { hydrogel combines microbicidal and wound healing } \\
\text { activities resulting in enhanced epithelization. Rejections } \\
\text { of transplants: } 8(9.9 \%) \text { vs. } 20(26.7 \%)\end{array}$ \\
\hline $\begin{array}{l}\text { Münter } \\
\text { (2006) [38] }\end{array}$ & $326 / 293$ & $\begin{array}{l}\text { Chronic } \\
\text { wounds } \\
\text { of various } \\
\text { aetiology } \\
\text { (VLU, AU, DFU, } \\
\text { PI, others) }\end{array}$ & $\begin{array}{l}\text { Sustained silver-releasing } \\
\text { foam dressing vs. best local } \\
\text { practice (BLP) (4 weeks) }\end{array}$ & $\begin{array}{l}\text { The foam dressing with a prolonged release mechanism } \\
\text { of silver ions (up to } 7 \text { days) exceeded BPL and all other } \\
\text { dressing categories in all aspects assessed (reduction } \\
\text { in the wound surface, reduction in exudate, fibrin and } \\
\text { necrosis; improved quality of life and longer wear time) }\end{array}$ \\
\hline $\begin{array}{l}\text { Daróczy } \\
(2006)[26]\end{array}$ & $21 / 21 / 21$ & $\begin{array}{l}\text { VLU (patients } \\
\text { presenting } \\
\text { ulcerated } \\
\text { stasis } \\
\text { dermatitis } \\
\text { due to deep } \\
\text { venous reflux) }\end{array}$ & $\begin{array}{l}\text { PVP-I with or without } \\
\text { compression therapy vs. } \\
\text { systemic antibiotic with } \\
\text { compression therapy } \\
\text { (12 weeks) }\end{array}$ & $\begin{array}{l}\text { Number of healings in individual groups: } 82 \%, 62 \%, 85 \% \\
\text { Recurrences of infections after } 5 \text { months: } 11 \%, 11 \%, 32 \%\end{array}$ \\
\hline $\begin{array}{l}\text { Lansdown } \\
\text { et al., } 2005 \\
\text { [39] }\end{array}$ & 7 & $\begin{array}{l}\text { Chronic } \\
\text { wounds } \\
\text { of various } \\
\text { aetiology }\end{array}$ & $\begin{array}{l}\text { Silver dressings (Acticoat-7, } \\
\text { Actisorb Silver, Contreet } \\
\text { Foam, Aquacel Ag and } \\
\text { Flamazine) }\end{array}$ & $\begin{array}{l}\text { Silver dressings were found to be safe for use in chronic } \\
\text { wound therapy }\end{array}$ \\
\hline $\begin{array}{l}\text { Karlsmark } \\
(2003)[40]\end{array}$ & 25 & VLU & $\begin{array}{l}\text { Sustained silver-releasing } \\
\text { dressing ( } 4 \text { weeks) without } \\
\text { any control group }\end{array}$ & $\begin{array}{l}\text { The tested dressing turned out to be safe, beneficial } \\
\text { for the healing process and ensuring control of } \\
\text { exudate: reduction in the ulcer area by } 56 \% \text {, increase in } \\
\text { granulation tissue, reduction in unpleasant odour (after } \\
1 \text { week), average wear time } 3.1 \text { days }\end{array}$ \\
\hline $\begin{array}{l}\text { Nagl (2003) } \\
{[42]}\end{array}$ & $20 / 20$ & Leg ulcers & $\begin{array}{l}\text { G1: N-chlorotaurine (NCT) } \\
\text { vs. chloramine T (CAT) } \\
\text { (median of } 7 \text { days (range: } \\
\text { 3-14)) }\end{array}$ & $\begin{array}{l}\text { Therapeutic effectiveness of treatment (decrease in } \\
\text { bacterial load) comparable. The intensity of pain in both } \\
\text { groups increased after the application of the preparation, } \\
\text { more so in the case of CAT (more often pain preventing } \\
\text { the continuation of therapy). Less toxicity, greater } \\
\text { granulation growth, and re-epithelization in NCT }\end{array}$ \\
\hline $\begin{array}{l}\text { Piérard- } \\
\text { Franchimont } \\
\text { (1997) [27] }\end{array}$ & $15 / 15$ & VLU & $\begin{array}{c}10 \% \text { PVP-J (Betadine) }+ \\
\text { hydrocolloid dressing vs. } \\
\text { hydrocolloid dressing alone } \\
\text { (8 weeks) }\end{array}$ & $\begin{array}{l}\text { Significantly better healing results were achieved in the } \\
\text { study group ( } 4 \text { and } 8 \text { weeks). Greater bacterial load and } \\
\text { inflammatory infiltrate in the group using the dressing } \\
\text { alone }\end{array}$ \\
\hline $\begin{array}{l}\text { Ormiston } \\
(1985)[32]\end{array}$ & $30 / 30$ & VLU & $\begin{array}{l}\text { Cadexomer iodine } 0.9 \% \\
\text { (powder) vs. dressing } \\
\text { with gentian violet and } \\
\text { polymyxin and bacitracin } \\
\text { ointment (12 weeks) }\end{array}$ & $\begin{array}{l}\text { Comparison of the effectiveness of two preparations } \\
\text { in cross-over therapy - } 12 \text {-week change of methods } \\
\text { between groups. Greater dynamics of healing, but } \\
\text { also more side effects (stinging, itching, eczema, rash) } \\
\text { in the group using iodine cadexomer. Improvement } \\
\text { in granulation, oedema, exudate, pus and erythema } \\
\text { comparable in both groups }\end{array}$ \\
\hline $\begin{array}{l}\text { Kucan (1981) } \\
{[28]}\end{array}$ & $15 / 11 / 14$ & $\mathrm{Pl}$ & $\begin{array}{c}\text { Silver sulfadiazine, } 1 \% \\
\text { (cream) vs. PVP-J vs. 0.9\% } \\
\mathrm{NaCl}(3 \text { weeks) }\end{array}$ & $\begin{array}{l}\text { All the preparations used resulted in the reduction in the } \\
\text { bacterial count below the critical level of 105/g of tissue } \\
\text { (after } 3 \text { weeks: } 100 \%, 78.6 \%, 63.6 \% \text { ), however, silver } \\
\text { sulfadiazine in a much shorter time }\end{array}$ \\
\hline
\end{tabular}

GPCR - real-time quantitative polymerase chain reaction, SEM - scanning electron microscopy, In RF-natural log reduction factor; (1 FR is a bacterial reduction factor, expressed as the natural logarithm, APP - cold atmospheric pressure plasma, TTP - tissue tolerable plasma, NT - TecophilicTM nanofibre textile, TPP - te traphenylporphyrin(photosensitizer), ROAT - repeated open application test, VLU - venous leg ulcer, AU - arterial ulcer, DFU - diabetic foot ulcer, PI - pressure injury, OCT - octenidine, PE - phenoxyethanol, PHMB - polyhexanide. 
duration of therapy ( 2 weeks vs. 6 weeks) and concentrations $[22,29,48]$. Therefore, long-term use of iodophors is not justified. With many substances there is a risk of iodine absorption from the wound surface. Due to the risk of systemic complications and irreversible damage to the thyroid gland, they are contraindicated in the course of thyroid diseases, in young children, premature babies and newborns. In healthy adults, single or short-term application is safe, however, due to the risk of temporary thyroid dysfunction and allergies, it is recommended to use PVP-I for a maximum of 7 days $[48,49]$. Despite the broad biocidal spectrum, iodophors are characterized by a high allergenic potential and cytotoxicity. Compared to OCT and PHMB, PVP-I has a much lower (i.e. borderline/ below normal) value of the biocompatibility index (0.91.0), which is not favourable for wounds with impaired healing potential. Most iodine preparations should not be used in the treatment of chronic wounds [6, 46, 47]. An exception is a modified form, povidone iodine liposome hydrogel. The macromolecular carrier system and the gradual release of liposomal iodine result in lower absorption, lower sensitization potential and cytotoxicity $[48,49]$. Clinical trials have shown good tissue tolerance of the preparation. PVP-I-L supported the healing of mesh grafts and donation sites in patients with ulceration, chronic wounds and burns, and reduced the risk of graft loss [24, 25].

Another analysed antimicrobial substance was polyhexanide (polyhexamethylene biguanide - PHMB), which in in vitro was characterized by a very favourable value of the $\mathrm{BI}=1.4-1.5$, slightly lower than OCT and higher than PVP-I [2, 6, 46]. In Poland, all preparations with PHMB are available in the medical device registration category. They are present in concentrations of $0.02 \%$ and $0.04 \%$ as a wound cleansing fluid, at a concentration of $0.1 \%$ in combination with betaine (i.e. a surfactant) as a wound cleansing fluid, and as a $0.1 \%$ hydrogel for wounds [14]. Three randomized clinical trials assessed the efficacy and antibacterial activity of PHMB preparations [22, 33, 43]. During the 4-week treatment of chronic wounds of the lower limbs and feet, a significant reduction in the bacterial load and better tolerance of the PHMB impregnated dressing (no complications, infections and less pain) than the control dressing was demonstrated [33]. In another study, irrigation of venous ulcers with $0.1 \%$ PHMB and betaine was more effective and resulted in significantly faster eradication of bacteria than saline irrigation. The use of PHMB was conducive to the reduction in odour from the wound [43]. In a study evaluating several different irrigation solutions - preparations containing PHMB and betaine showed measurable and significant bacterial reduction in the bed of chronic wounds. One of the preparations was significantly more effective (the most effective among all assessed products) than the other, whose bacterial reduction index was on the border of statistical significance. Both were more effective than saline [22].

In the same randomized trial, a comparative evaluation of several other wound irrigation substances was performed, including those containing OCT, PHMB, PVP-I, hypochlorites, sea salt, hypertonic salt, a combination of two/more formulations, and $0.9 \% \mathrm{NaCl}$ as control [22]. All the solutions used, except saline and lithium-magnesium-sodium solution with active oxygen, resulted in measurable and significant bacterial reduction in the wound swab. The best result - from the above-mentioned betaine aqueous solution with PHMB, zinc and iron - was achieved with a 3\% sea salt solution with $0.2 \% \mathrm{NaOCl}$, PVP-I and a solution of sodium hypochlorite with hypochlorous acid. It should be emphasized, however, that this study only assessed the antimicrobial efficacy of the preparations (the number of microorganisms was compared before and 20 min after wound cleaning), but did not assess their tolerance and effect on the wound healing process. Based on the results of this study, it is difficult to draw conclusions about the effects of long-term therapy and the tolerance of individual preparations. It is worth emphasizing, however, an interesting observation resulting from the combination of two different irrigation solutions (here: OCT with PHMB). Contrary to the authors' expectations, no synergistic effect was observed, but a decrease in the effectiveness of the preparations (compared to the action of each of them separately) and a significantly lower bacterial reduction index. It is therefore not justified to combine different types of preparations from the same registration group.

Many studies have compared single antimicrobials to placebo or standard care. Irrigation fluids and gels (with $\mathrm{OCT}, \mathrm{PHMB})[17,23,33,34]$ and dressings (mainly with Ag) were assessed [31, 36-38, 40]. The use of all the above-mentioned methods gave significantly better treatment effects than in the control groups. Combined care was also beneficial, combining various methods of therapy, e.g. local with causal, or physical cleansing with the chemical action of an antiseptic. The combination of dressings with an antimicrobial preparation (OCT, PHMB) was better than the special dressing itself $[17,23,33]$. In one of the studies, the "sandwich" dressing was used, consisting of several layers: octenidine in a gel, a specialized hydrophobic dressing and an external absorbent dressing. The wound was washed with a liquid OCT antiseptic. In the control group, a specialized Ag dressing and an external absorbent dressing were used, but the wound was washed with a neutral Ringer's solution. Octenidine used in the form of a drug - an antiseptic and a medical device (lavaseptic and gel) gave significantly better results in the treatment of venous ulcers than the dressing itself, despite the silver content [17]. Other authors also observed that the lavaseptic supported by a compatible antiseptic [17], the combination of octenidine preparations with the physical action (cold atmos- 
pheric pressure plasma) $[18,19]$ and the combination of antimicrobial preparations with compression therapy in the course of VLU $[17,26]$ were significantly more effective than either method alone.

Interesting results were obtained by Madhusudhan [41] on the use of acetic acid in the treatment of chronic wounds infected with Pseudomonas aeruginosa. The blue pus bacterium is a pathogen that is particularly difficult to eradicate. It has a natural resistance to many antibiotics, and in the case of chronic wounds it is additionally enhanced by the bacteria's ability to create biofilm. When using acetic acid, the authors were guided by the knowledge that the acidic environment of the wound facilitates the control of infection, promotes the inhibition of bacterial proteases and metabolites, and accelerates epithelization and angiogenesis [50]. The use of an antiseptic preparation reduces the risk of bacterial resistance development and is a much better solution than antibiotics. Madhusan used 1\% acetic acid in a 24-week study, but Kramer [6] reported that concentrations of 1-5\% were acceptable $[6,50]$. It was shown that the mean time of P. aeruginosa eradication was 7 days shorter than in the control group. Apart from pain and burning/discomfort, no other complications were found. Contraindications to the use of acetic acid were not given. In our review, this was the only study looking at the use of acids in chronic wounds. Perhaps the next ones will increase the popularity of fruit acids in the treatment of multi-drug-resistant infections and support the eradication of biofilm. Meanwhile, the study by Wolcott [44] and Kim [51] used a specialist antimicrobial gel to heal wounds, based on the patented, non-toxic $\mathrm{Xbio}^{\mathrm{TM}}$ technology by Next Science. The manufacturer states that it deconstructs the bacterial biofilm EPS matrix, destroys bacteria within the gel and defends from recolonization while maintaining a moist wound environment [52]. In clinical trials, the gel was compared with standard care [44] and with triple-antibiotic ointment (including neomycin, polymyxin B, and bacitracin) [51]. In both cases, the biofilm-degrading antimicrobial gel was more effective - the group using the gel alone had a significantly greater reduction in wound area than the standard care group, but the best results were achieved when combining specialist care with gel (over 12 as much as 95\% of the wound surface will heal) [51]. The performed microbiological analysis showed no correlation between the presence of bacteria in the wound, or between the number of identified species of microorganisms and the effect on the healing process. The frequency of vancomycin and methicillin-resistant genes assessed by polymerase chain reaction (PCR) was so low that it did not provide sufficient power for statistical evaluation. These data, according to the authors of the review, are not sufficient to draw unambiguous conclusions confirming the degradation of biofilm by the gel used in clinical conditions.
Similarly, when it comes to the evaluation of a new dressing material based on a polyurethane nanofiber fabric prepared by the nanofibre textile method with an admixture of tetraphenylporphyrin as a photosensitizer activated by visible light. One of the studies investigated the antimicrobial activity, the effect on the healing of venous ulcers, and the safety of the material. High efficiency of the dressing was demonstrated (significant inhibition of bacterial growth, reduction in the wound area by $35 \%$ and pain reduction by $71 \%$ ). Bacterial photoinactivation, dependent on the production of highly reactive, short-lived singlet oxygen $\mathrm{O}_{2}(1 \mathrm{Dg})$ resulted in a relatively superficial antimicrobial effect (only on the material surface) compared to standard antiseptic treatment options. The authors emphasized that in the future this method may become an alternative to the topical application of antiseptics and antibiotics, as it does not interfere with the normal healing process and has no side effects [43].

\section{Conclusions}

Our analysis made it possible to systematize the results of clinical trials conducted so far concerning the use of antimicrobial substances in the treatment of chronic wounds. New generation antiseptics and antimicrobial preparations are highly effective, both in the prevention and treatment of infections, and are well tolerated by the tissues and do not interfere with the healing process. Nevertheless, they should not be used routinely. Clean and colonized wounds do not require antiseptics. Antiseptics are recommended for wounds showing clinical symptoms of infection, at risk of infection and in patients with disorders of the immune system or accompanying chronic diseases. According to experts' suggestions, it is worth using a parametric risk assessment using e.g. the W.A.R. (Wounds at Risk Score) to help you make the right clinical decision. Among the antiseptic preparations currently available on the market, octenidine (OCT/PE, 0.1\%) seems to be the most effective and safest, which - unlike PVP-I - can be used in the treatment of chronic wounds and ulcers. For cleaning, we recommend OCT-based irrigation fluids, $\mathrm{PHMB}$, or hypochlorite. The maintenance of the antimicrobial effect during the therapy is ensured by a compatible dressing that sequesters microorganisms and/or contains an antibacterial substance, e.g. silver. This review points out that the preparation itself is not sufficient, and the therapeutic effect depends to the greatest extent on properly selected causal therapy, preceded by thorough diagnostics. Moreover, only comprehensive and multidirectional therapy can give a lasting and long-term effect, prevent recurrence of infections and, after healing, also relapse of ulcers. These activities include the healing of the wound bed and its preparation for the application of the preparation in accordance with the current TIME strategy, they include: debridement and 
cleaning the wound, ensuring the moisture balance and stimulation of epithelialization and granulation.

\section{Conflict of interest}

The authors declare no conflict of interest.

\section{References}

1. Głowala S. The history of asepsis and antisepsis. Forum Zakażeń 2018; 9: 1-4.

2. Kramer A, Daeschlein G, Kammerlander G, et al. An assessment of the evidence on antiseptics: a consensus paper on their use in wound care. J Wound Care 2004; 13: 1-7.

3. Jawień A, Bartoszewicz M, Przondo-Mordarska A, et al. Guidelines for local and general management in wounds subject to the infection process. Leczenie Ran 2012; 3: 59-75.

4. Bartoszewicz M, Banasiewicz T, Bielecki K. et al. Principles of local and systemic treatment of infected wounds and chronic ulcers. Guidelines. Forum Zakażeń 2019; 10: 1-30.

5. Bartoszewicz M, Junka A. Biofilm based wound care: a strategy for the treatment of chronic wounds with an infectious process caused by microorganisms in a biofilm form. Leczenie Ran 2012; 9: 1-6.

6. Kramer A, Dissemond J, Kim S, et al. Consensus on wound antisepsis: update 2018. Skin Pharmacol Physiol 2018; 31: 28-58.

7. Dissemond J, Assadian O, Gerber V. Classification of wounds at risk and their antimicrobial treatment with polihexanide: a practice-oriented expert recommendation. Skin Pharmacol Physiol 2011; 24: 245-55.

8. Office for Registration of Medicinal Products, Medical Devices and Biocidal Products (http://urpl.gov.pl/).

9. Pharmaceutical Law Act of 6 September 2001 (Journal of Laws of 2020, item 944).

10. The Act on medical devices of 20 May 2010 (Journal of Laws of 2020, item 186).

11. Regulation of the Minister of Health on the determination of groups of medicinal products and the requirements for the results of testing these products of 11 August 2005 (Journal of Laws of 24 August 2005).

12. Szewczyk MT, Cwajda-Białasik J, Mościcka P, et al. Recommendations for the prevention of surgical site infections and use of antibiotic therapy during preoperative nursing care in surgery departments. Piel Chirur Angiol 2015; 2: 56-72.

13. Szewczyk MT, Mościcka P, Cwajda-Białasik J, et al. Recommendations for the prevention of surgical site infections during postoperative nursing care in surgery departments. Piel Chirur Angiol 2015; 2: 92-110.

14. Sopata M, Banasiewicz T, Gabriel M, et al. Raport. Review of antimicrobial substances used in wound treatment based on the German consensus and Polish guidelines (2018 state of knowledge); 2019. https://zagojeni.pl/wp-content/uploads/2018/10/RAPORT_przegl\%C4\%85d-substancji-stosowanych-w-leczeniu-ran.pdf.

15. Gasca-Lozano LE, Lucano-Landeros S, Ruiz-Mercado H, et al. Pirfenidone accelerates wound healing in chronic diabetic foot ulcers: a randomized, double-blind controlled trial. J Diabetes Res 2017; 2017: 3159798.

16. Bishop JB, Phillips LG, Mustoe TA, et al. A prospective randomized evaluator-blinded trial of two potential wound healing agents for the treatment of venous stasis ulcers. J Vasc Surg 1992; 16: 251-7.
17. Krasowski G, Jawień A, Tukiendorf A, et al. A comparison of an antibacterial sandwich dressing vs dressing containing silver. Wound Repair Regen 2015; 23: 525-30.

18. Ulrich C, Kluschke F, Patzelt A, et al. Clinical use of cold atmospheric pressure argon plasma in chronic leg ulcers: a pilot study. J Wound Care 2015; 24: 196-203.

19. Klebes M, Ulrich C, Kluschke F, et al. Combined antibacterial effects of tissue-tolerable plasma and a modern conventional liquid antiseptic on chronic wound treatment. J Biophotonics 2015; 8: 382-91.

20. Vanscheidt W, Harding K, Téot L, et al. Effectiveness and tissue compatibility of a 12 -week treatment of chronic venous leg ulcers with an octenidine based antiseptic - a randomized, double-blind controlled study. Int Wound I 2012; 9: 316-23.

21. Calow T, Oberle K, Bruckner-Tuderman L, et al. Contact dermatitis due to use of Octenisept in wound care. J Dtsch Dermatol Ges 2009; 7: 759-65.

22. Assadian O, Kammerlander G, Geyrhofer C, et al. Use of wetto-moist cleansing with different irrigation solutions to reduce bacterial bioburden in chronic wounds. J Wound Care 2018; 27 (Suppl 10): S10-6.

23. Hämmerle G, Strohal R. Efficacy and cost-effectiveness of octenidine wound gel in the treatment of chronic venous leg ulcers in comparison to modern wound dressings. Int Wound J 2016; 13: 182-8.

24. Hauser J, Rossbach O, Vogt PM, et al. Efficacy of treatment with Repithel and Jelonet in comparison to treatment with Jelonet alone - a randomized clinical trial in patients receiving meshed skin grafts. Zentralbl Chir 2006; 131: 315-21.

25. Vogt PM, Reimer K, Hauser J, et al. PVP-iodine in hydrosomes and hydrogel - a novel concept in wound therapy leads to enhanced epithelialization and reduced loss of skin grafts. Burns 2006; 32: 698-705.

26. Daróczy J. Quality control in chronic wound management: the role of local povidone-iodine (Betadine) therapy. Dermatology 2006; 212 Suppl 1: 82-7.

27. Piérard-Franchimont C, Paquet P, Arrese JE, et al. Healing rate and bacterial necrotizing vasculitis in venous leg ulcers. Dermatology 1997; 194: 383-7.

28. Kucan JO, Robson MC, Heggers JP, et al. Comparison of silver sulfadiazine, povidone-iodine and physiologic saline in the treatment of chronic pressure ulcers. JAm Geriatr Soc 1981; 29: 232-5.

29. Malone M, Schwarzer S, Radzieta M, et al. Effect on total microbial load and community composition with two vs sixweek topical Cadexomer lodine for treating chronic biofilm infections in diabetic foot ulcers. Int Wound J 2019; 16: 147786.

30. Raju R, Kethavath SN, Sangavarapu SM, et al. Efficacy of cadexomer iodine in the treatment of chronic ulcers: a randomized, multicenter, controlled trial. Wounds 2019; 31: 85-90.

31. Miller CN, Newall N, Kapp SE, et al. A randomized-controlled trial comparing cadexomer iodine and nanocrystalline silver on the healing of leg ulcers. Wound Repair Regen 2010; 18: 359-67.

32. Ormiston MC, Seymour MT, Venn GE, et al. Controlled trial of lodosorb in chronic venous ulcers. Br Med J 1985; 291: 308-10.

33. Sibbald RG, Coutts $P$, Woo KY. Reduction of bacterial burden and pain in chronic wounds using a new polyhexamethylene biguanide antimicrobial foam dressing-clinical trial results. Adv Skin Wound Care 2011; 24: 78-84. 
34. Romanelli M, Dini V, Barbanera S, Bertone MS. Evaluation of the efficacy and tolerability of a solution containing propyl betaine and polihexanide for wound irrigation. Skin Pharmacol Physiol 2010; 23 Suppl: 41-4.

35. Woo KY, Coutts PM, Sibbald RG. A randomized controlled trial to evaluate an antimicrobial dressing with silver alginate powder for the management of chronic wounds exhibiting signs of critical colonization. Adv Skin Wound Care 2012; 25: 503-8.

36. Trial C, Darbas H, Lavigne JP, et al. Assessment of the antimicrobial effectiveness of a new silver alginate wound dressing: a RCT. J Wound Care 2010; 19: 20-6.

37. Kotz P, Fisher J, McCluskey P, et al. Use of a new silver barrier dressing, ALLEVYN Ag in exuding chronic wounds. Int Wound I 2009; 6: 186-94.

38. Münter KC, Beele H, Russell L, et al. Effect of a sustained silver-releasing dressing on ulcers with delayed healing: the CONTOP study. J Wound Care 2006; 15: 199-206.

39. Lansdown AB, Williams A, Chandler S, Benfield S. Silver absorption and antibacterial efficacy of silver dressings. J Wound Care 2005; 14: 155-60.

40. Karlsmark T, Agerslev RH, Bendz SH, et al. Clinical performance of a new silver dressing, contreet foam, for chronic exuding venous leg ulcers. J Wound Care 2003; 12: 351-4.

41. Madhusudhan VL. Efficacy of $1 \%$ acetic acid in the treatment of chronic wounds infected with Pseudomonas aeruginosa: prospective randomised controlled clinical trial. Int Wound 2016; 13: 1129-36

42. Nagl M, Nguyen VA, Gottardi W, et al. Tolerability and efficacy of $\mathrm{N}$-chlorotaurine in comparison with chloramine $\mathrm{T}$ for the treatment of chronic leg ulcers with a purulent coating: a randomized phase II study. Br J Dermatol 2003; 149: 590-7.

43. Arenbergerova M, Arenberger P, Bednar M, et al. Light-activated nanofibre textiles exert antibacterial effects in the setting of chronic wound healing. Exp Dermatol 2012; 21: 619-24.

44. Wolcott R. Disrupting the biofilm matrix improves wound healing outcomes. I Wound Care 2015; 24: 366-71.

45. Kramer A, Kremer J, Assadian O, et al. The classification of antiseptic products to be administered to wounds - another borderline case between medicinal products and medical devices? Int J Clin Pharmacol Ther 2006; 44: 677-92.

46. Müller G, Kramer A. Biocompatibility index of antiseptic agents by parallel assessment of antimicrobial activity and cellular cytotoxicity. J Antimicrob Chemother 2008; 61: 1281-7.

47. Kramer A, Reichwagen S, Heldt P, et al. Oxidanzien. In: Wallhäussers Praxis der Sterilisation, Desinfektion, Antiseptik und Konservierung. Kramer A, Assadian O (eds.). Thieme, Stuttgart 2008; 713-45.

48. Capriotti K, Capriotti JA. Topical iodophor preparations: chemistry, microbiology, and clinical utility. Dermatol Online J 2012; 18: 11.

49. Reimer K, Vogt PM, Brögmann B, et al. An innovative topical drug formulation for wound healing and infection treatment: in vitro and in vivo investigations of a povidone iodine liposome hydrogel. Dermatology 2000; 201: 235-41.

50. Nagoba BS, Selkar SP, Wadher BJ, et al. Acidic environment and wound healing: a review. Wounds 2015; 27: 5-11.

51. Kim D, Namen W, Moore J, et al. Clinical assessment of a biofilm-disrupting agent for the management of chronic wounds compared with standard of care: a therapeutic approach. Wounds 2018; 30: 120-30.

52. https://www.nextscience.com/blastx-wound-gel/ 